\title{
Tuberculosis along the United States-Mexico border, 1993-2001
}

\author{
Eileen Schneider, ${ }^{1}$ Kayla F. Laserson, ${ }^{1}$ Charles D. Wells, ${ }^{1}$ \\ and Marisa Moore ${ }^{1}$
}

Suggested citation: Schneider E, Laserson KF, Wells CD, Moore M. Tuberculosis along the United States-Mexico border, 1993-2001. Rev Panam Salud Publica. 2004;16(1):23-34.

ABSTRACT Objectives. Tuberculosis (TB) is a leading public health problem and a recognized priority for the federal Governments of both Mexico and the United States of America. The objectives of this research, primarily for the four states in the United States that are along the border with Mexico, were to: (1) describe the epidemiological situation of $T B,(2)$ identify $T B$ risk factors, and (3) discuss tuberculosis program strategies.

Methods. We analyzed tuberculosis case reports collected from 1993 through 2001 by the tuberculosis surveillance system of the United States. We used those data to compare TB cases mainly among three groups: (1) Mexican-born persons in the four United States border states (Arizona, California, New Mexico, and Texas), (2) persons in those four border states who had been born in the United States, and (3) Mexican-born persons in the 46 other states of the United States, which do not border Mexico.

Results. For the period from 1993 through 2001, of the 16223 TB cases reported for Mexicanborn persons in the United States, 12450 of them (76.7\%) were reported by Arizona, California, New Mexico, and Texas. In those four border states overall in 2001, tuberculosis case rates for Mexican-born persons were 5.0 times as high as the rates for persons born in the United States; those four states have 23 counties that directly border on Mexico, and the ratio in those counties was 5.8. HIV seropositivity, drug and alcohol use, unemployment, and incarceration were significantly less likely to be reported in Mexican-born TB patients from the four border states and the nonborder states than in patients born in the United States from the four border states $(\mathrm{P}<0.001)$. Multivariate analysis revealed that among pulmonary tuberculosis patients who were 18-64 years of age and residing in the four border states, the Mexican-born patients were 3.6 times as likely as the United States-born patients were to have resistance to at least isoniazid and rifampin (i.e., to have multidrug-resistant TB) and twice as likely to have isoniazid resistance. Mexican-born TB patients from the four border states and the nonborder states were significantly more likely to have moved or to be lost to follow-up than were the TB patients born in the United States from the four border states $(\mathrm{P}<0.001)$.

Conclusions. Increased collaborative tuberculosis control efforts by the federal Governments of both Mexico and the United States along the border that they share are needed if tuberculosis is to be eliminated in the United States.

Key words Tuberculosis, population surveillance, antitubercular agents, Mexico, United States, international cooperation.

1 United States, Centers for Disease Control and Prevention, Division of Tuberculosis Elimination, Atlanta, Georgia, United States of America. Send correspondence to: Eileen Schneider, Division of Tuberculosis Elimination, CDC, 1600 Clifton Road, MS E-10, Atlanta, Georgia 30333, United States of
America; telephone: 404-639-5345; fax: 404-639-8959; e-mail: eschneider@cdc.gov 
FIGURE 1. United States-Mexico border map, 2001

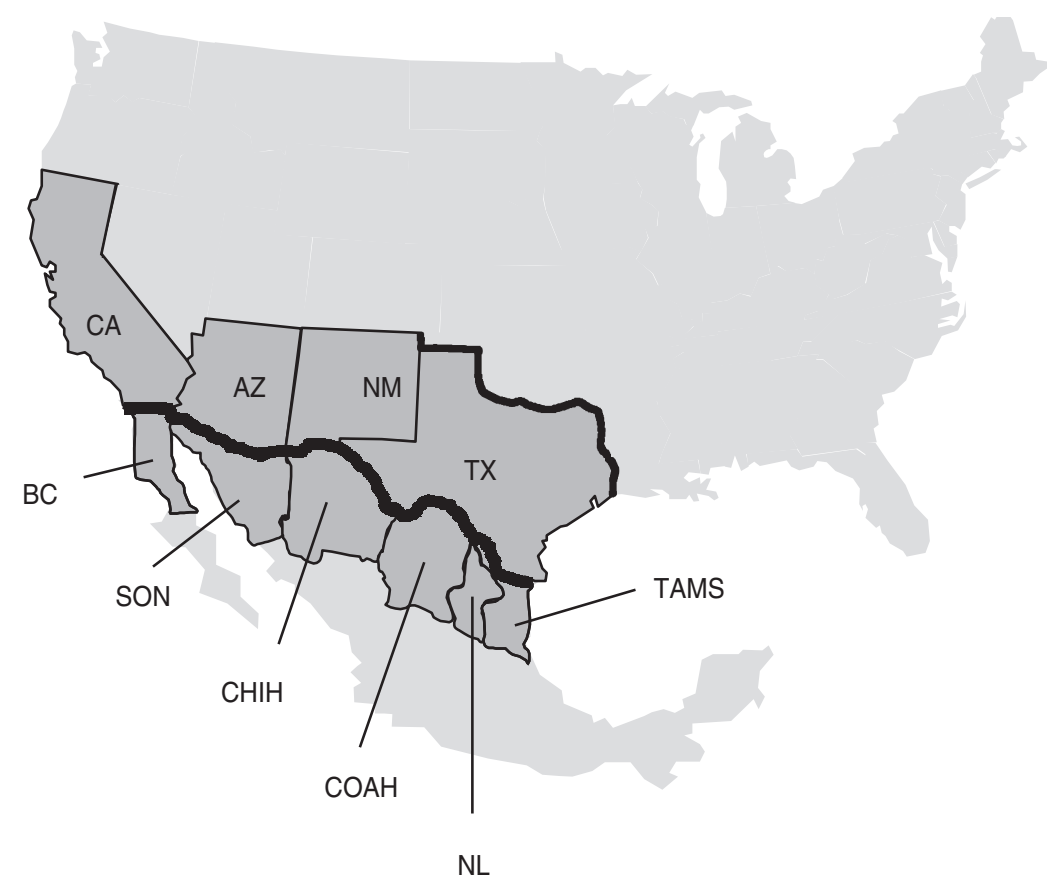

United States-Mexico border

- States: four in the United States, six in Mexico

- Length: 1952 miles (3 141 kilometers) (3)

- Border area a population: 11.5 million persons (1)

- Annual northbound border crossings: 264 million persons (4)

\begin{tabular}{lrrr} 
& TB cases $^{\mathrm{b}}$ & & TB rate \\
\cline { 2 - 2 } Arizona (AZ) & 289 & & 5.4 \\
California (CA) & 3332 & & 9.7 \\
New Mexico (NM) & 54 & & 3.0 \\
Texas (TX) & 1643 & & 7.7 \\
\hline U.S. border states & 5318 & 8.4 \\
\hline U.S. national & 15989 & & 5.6 \\
Baja California Norte (BC) & 1321 & & 54.0 \\
Chihuahua (CHIH) & 533 & & 17.1 \\
Coahuila (COAH) & 150 & 6.2 \\
Nuevo León (NL) & 1221 & 31.1 \\
Sonora (SON) & 514 & & 22.6 \\
Tamaulipas (TAMS) & 1041 & & 37.5 \\
\hline Mexican border states & 4780 & 28.1 \\
\hline Mexican national & 16323 & & 16.2
\end{tabular}

a Border area is defined as the area extending 100 kilometers (62 miles) north-south on either side of the United States-Mexico border.

b Sources: United States TB data: Centers for Disease Control and Prevention. Reported tuberculosis in the United States, 2001. Atlanta: United States Department of Health and Human Services, CDC; 2002 (2). Mexican TB data: Sistema Único de Información para la Vigilancia Epidemiológica/Dirección General de Epidemiología/Secretaría de Salud.

${ }^{c}$ TB rate $=$ TB cases per 100000 population.

Tuberculosis (TB) among populations along the border shared by Mexico and the United States of America is a leading public health problem and a recognized priority for the federal Governments of the two countries (1). There are four states in the United States and six states in Mexico along the United States-Mexico border. As shown in Figure 1, in 2001, TB rates on each side of the border were 1.5 times their respective national averages, according to published (1-4) and unpublished sources. ${ }^{2}$ Prolonged infectiousness, ongoing transmission, and increased drug resistance have been documented among TB patients residing along the border (5-9). Moreover,

2 Velázquez Monroy O. Epidemiological situation of tuberculosis in Mexico. Presentation made at United States-Mexico Binational Tuberculosis Workshop, 14-16 October 2001, El Paso, Texas, United States.
TB control, including TB case management and completion of the standard six-month treatment regimen, is made more difficult in this area by poor socioeconomic conditions, limited health care access, and an extremely mobile population $(1,4,10-13)$.

In $2001,49 \%$ of the total TB cases reported in the United States were among foreign-born persons. Almost one-quarter of the foreign-born TB patients $(23 \%)$ were born in Mexico, and $69 \%$ of these Mexican-born TB patients were reported from Arizona, California, New Mexico, and Texas, the four states in the United States that border Mexico (2). The health of immigrant populations in the United States, and of the Mexican-born population in particular, is of increasing importance, as 31.1 million people in the United States are foreign-born and almost one-third of them (9.2 million) are of Mexican origin, the largest subgroup (14).
Growing concerns about the TB problem along the United StatesMexico border have led to recent local and federal strategic public health initiatives in both Mexico and the United States, including a mandate for increased TB control efforts $(1,15-21)$. We sought to describe TB along the United States-Mexico border in order to identify TB risk factors as well as to use the information to facilitate case management and prevention of TB along the United States-Mexico border. Using data for 1993 through 2001 collected by the national TB surveillance system of the United States, we compared TB cases among three groups: (1) the Mexican-born population in the four United States border states, (2) persons in those four border states who were born in the United States, and (3) Mexican-born persons residing in the 46 other states of the United States, which do not border Mexico. 


\section{METHODS}

The national TB surveillance system of the United States uses a standardized case report form to collect information on newly diagnosed persons with TB from the 50 states and the District of Columbia (i.e., Washington, D.C.) (22). Completed for each reported $\mathrm{TB}$ case, the form contains demographic, clinical, laboratory, and sociodemographic information, including country of origin, date of arrival in the United States, human immunodeficiency virus (HIV) seropositivity status, and anti-TB drug resistance. In the state of California, instead of reporting HIV test results, TB and acquired immunodeficiency syndrome (AIDS) registries are compared annually, and TB patients found on the AIDS registry are reported as testing positive for HIV infection; all other California TB cases are classified as having an unknown HIV status for the purpose of data analysis. For our study we analyzed national TB surveillance data collected in the United States from 1993 through 2001.

We used the United States Census Bureau definition of a native or a person born in the United States and also the Bureau's definition of foreign-born status (23). Persons were classified as a native or as born in the United States if: (1) they were born in one of the 50 states, the District of Columbia, or a United States territory, "island area," or "outlying area" (e.g., Puerto Rico, Guam) or (2) they were born outside the United States to at least one parent who was a United States citizen. All other persons were classified as foreign-born.

In order to evaluate TB among Mexican-born persons and along the United States-Mexico border, we compared Mexican-born persons in the four United States border states (Arizona, California, New Mexico, and Texas) to Mexican-born persons in the 46 nonborder states in the United States and to persons who had been born in the United States and were residing in the four United States border states. We used data for 1993 through
2001 that had been collected by the national TB surveillance system of the United States. Non-Mexican foreignborn TB patients from the four United States border states ("other foreignborn border") were compared to Mexican-born TB patients for specific variables (e.g., years spent in United States prior to TB diagnosis).

The Centers for Disease Control and Prevention (CDC) National TB Surveillance System is an approved data collection system and has been determined by the Associate Director of Science, CDC, National Center for HIV, STD and TB Prevention as not constituting research. Therefore, specific institutional review board approval was not needed for this study. The CDC National TB Surveillance System is considered routine disease surveillance and does not constitute human or animal subjects research.

\section{Analysis}

Population data used to calculate rates were obtained from the United States Census Bureau, Census 2000 (24). Population data from the Census 2000 for persons born in the United States were calculated by subtracting foreign-born population data from total population data. For our univariate analysis, we calculated relative risks (RRs), 95\% confidence intervals (CIs), and two-tailed $P$ values using a Mantel-Haenszel chi-square $\left(\chi^{2}\right)$ test for dichotomous variables. Unknown values were excluded when calculating the relative risk and odds ratio, except for HIV status. Multivariate logistic regression was used to determine factors associated with multidrug resistance (i.e., resistance to at least isoniazid and rifampin) and resistance to isoniazid among pulmonary TB patients 18 to 64 years of age. Potential covariates for the logistic regression models included those with $P<0.20$ in univariate analysis, known confounders, and those considered to be epidemiologically relevant. Epidemiologically plausible interactions were tested; none was significant. The corre- lation coefficients for all variables introduced into the model were less than 0.5. The SAS 8.2 (25), Epi Info 6.04d (26), and Stata 7.0 (27) software programs were used for analysis; a result was determined to be statistically significant if $P<0.05$.

\section{RESULTS}

From 1993 through 2001 a total of 181111 new TB cases were reported in the United States, of which 69232 $(38.2 \%)$ were among foreign-born persons. The proportion of TB cases among foreign-born persons significantly increased over that time period, from $29.5 \%$ (7 399/25 109) in 1993 to $49.2 \%(7865 / 15989)$ in 2001 ( $\chi^{2}$ for trend, $P<0.001)$. The country contributing the largest number of foreignborn TB cases was Mexico, with 1874 $(25.3 \%)$ of the 7399 cases reported in 1993 and $1845(23.5 \%)$ of the 7865 cases reported in 2001. The majority of Mexican-born TB patients were consistently reported by the four border states (Arizona, California, New Mexico, and Texas); those four states reported $76.7 \%$ (12 450/16 223) of the total Mexican-born TB patients from 1993 through 2001, and they reported $68.8 \%$ (1 269/1 845) in 2001. In 2001 seven states in the United States reported 50 or more Mexican-born TB cases and together comprised greater than $80 \%$ of the national total of Mexican-born TB cases: California (791 cases), Texas (388 cases), Arizona (82 cases), Illinois (75 cases), Florida (62 cases), North Carolina (58 cases), and New York (51 cases). In 2001, Mexicanborn TB patients represented approximately one-quarter of the total number of reported cases in the states of Arizona $(28.4 \%)$, Colorado $(25.4 \%)$, California $(23.7 \%)$, Texas $(23.6 \%)$, and Oregon $(20.3 \%)$.

TB case rates were many times higher among Mexican-born persons than among persons born in the United States, especially in United States counties along the border (i.e., counties in the United States that are contiguous to the United States-Mexico border) 
TABLE 1. Mexican-born and U.S.-born tuberculosis (TB) cases and TB case rates by area, United States (U.S.), 2001

\begin{tabular}{|c|c|c|c|c|}
\hline \multirow[b]{2}{*}{ Area } & \multicolumn{2}{|c|}{ Mexican-born TB cases } & \multicolumn{2}{|c|}{ U.S.-born TB cases } \\
\hline & No. & Rate $^{a}$ & No. & Rate $^{a}$ \\
\hline \multicolumn{5}{|l|}{ Arizona } \\
\hline State & 82 & 18.8 & 152 & 3.4 \\
\hline 4 border counties $^{b}$ & 28 & 23.2 & 34 & 3.4 \\
\hline \multicolumn{5}{|l|}{ California } \\
\hline State & 791 & 20.1 & 840 & 3.3 \\
\hline 2 border counties ${ }^{b}$ & 131 & 39.0 & 112 & 4.8 \\
\hline \multicolumn{5}{|l|}{ New Mexico } \\
\hline State & 8 & 7.5 & 42 & 2.5 \\
\hline 3 border counties ${ }^{b}$ & 2 & 5.7 & 4 & 2.4 \\
\hline \multicolumn{5}{|l|}{ Texas } \\
\hline State & 388 & 20.6 & 934 & 5.2 \\
\hline 14 border counties $^{b}$ & 142 & 27.3 & 106 & 7.5 \\
\hline Total border states (4 states) & 1269 & 20.0 & 1968 & 4.0 \\
\hline Total border counties ${ }^{b}$ ( 23 counties) & 303 & 30.0 & 256 & 5.2 \\
\hline Total nonborder states (46 states) & 576 & 20.4 & 5877 & 2.9 \\
\hline U.S. national & 1845 & 20.1 & 7845 & 3.1 \\
\hline
\end{tabular}

${ }^{a}$ Rate $=$ TB cases per 100000 population; 2001 TB case rate calculated using 2000 Census (Summary File 3), United States Census Bureau (24).

${ }^{\mathrm{b}}$ Border counties $=$ counties in the United States that are contiguous to the United States-Mexico border.

(Table 1). In 2001 in the four border states together, TB case rates for Mexican-born persons were 5.0 times as high as the rates for persons born in the United States; in the 23 counties on the border with Mexico, that ratio was 5.8. In that same year the TB case rate among Mexican-born persons was similar for the four border states (20.0 per 100000 population) and the 46 nonborder states (20.4 per 100000 population). Also in 2001, among TB cases in California and Texas in persons who had been born in the United States, case rates were higher among persons living in the border counties than they were for the state overall.

From 1993 through 2001, among both the United States-born and Mexican-born cases, the age group contributing the largest proportion to the TB burden were persons 25 to 44 years old. However, among pediatric TB patients (i.e., $<15$ years old), the proportion of United States-born borderstate patients was around twice that of both Mexican-born border-state patients $(\mathrm{RR}=1.8 ; 95 \% \mathrm{CI}, 1.7-1.9)$ and Mexican-born nonborder-state patients
$(\mathrm{RR}=2.0 ; 95 \%$ CI 1.8-2.3) (Table 2). Pulmonary TB was found in greater than $80 \%$ of TB cases (Mexican-born border: 83.7\%; United States-born border: $84.3 \%$; Mexican-born nonborder: 80.6\%). Among adult pulmonary TB patients (i.e., $\geq 15$ years old), positive sputum smears for acid-fast bacilli were more frequently reported for Mexican-born TB patients (border: $52.0 \%$; nonborder: $56.2 \%$ ) than for United States-born border TB patients $(46.0 \%)$. However, the proportion of positive sputum cultures for Mycobacterium tuberculosis was similar for Mexican-born TB patients (border: $77.1 \%$; nonborder: $77.8 \%$ ) and United Statesborn border patients (74.4\%). Among pulmonary TB cases, more than $92 \%$ of chest radiographs were abnormal for all comparison groups. However, among persons with an abnormal chest radiograph, the proportion of Mexican-born patients with cavitary disease (border: 29.4\%; nonborder: $32.4 \%$ ) was significantly higher than that of United States-born border patients $(25.5 \%)\left(\chi^{2}, P<0.001\right.$ for both comparisons). HIV test results were not available for a large proportion of TB patients 25 to 44 years of age, especially along the border (Table 2). However, United States-born border TB patients were more than twice as likely to be coinfected with HIV as Mexicanborn TB patients; this was true both for Mexican-born TB patients in the border states $(\mathrm{RR}=2.1 ; 95 \% \mathrm{CI}, 2.0-2.3)$ and for those in the nonborder states $(\mathrm{RR}=2.8$; 95\% CI, 2.4-3.2). Adult Mexican-born border TB patients had resided in the United States for a longer period of time before TB was diagnosed (median: 10.0 years; diagnosed within 5 years: $29.9 \%$; diagnosed after 5 years: $59.6 \%$; unknown: $10.5 \%)$ than either Mexican-born nonborder patients (median: 4.0 years; diagnosed within 5 years: $47.3 \%$; diagnosed after 5 years: $37.4 \%$; unknown: $15.3 \%$ ) or border TB patients born in countries other than Mexico (median: 6.6 years; diagnosed within 5 years: $39.6 \%$; diagnosed after 5 years: $52.8 \%$; unknown: $7.6 \%$ ).

Among persons aged 18 to 64 years the proportions of TB cases in United States-born border residents who were in a correctional facility (e.g., jail, prison) at diagnosis (12.4\%); had used injecting drugs $(7.9 \%)$, noninjecting drugs $(14.4 \%)$, or excess alcohol $(24.9 \%)$ within the past year; or were homeless $(16.0 \%)$ within the past year were significantly greater than in Mexican-born border TB patients $(7.3 \%, 2.7 \%, 6.4 \%$, $16.1 \%$, and $6.6 \%$, respectively); the same was true for Mexican-born nonborder TB patients $(3.5 \%, 1.0 \%, 3.0 \%$, $12.2 \%$, and $6.4 \%$, respectively) (Table 3 ) $\left(\chi^{2}, P<0.001\right.$ for all comparisons). Except for a history of homelessness, Mexican-born border TB patients reported those five risk factors more frequently than did Mexican-born nonborder TB patients $\left(\chi^{2}, P<0.001\right.$ for all comparisons). United States-born border TB patients reported being unemployed during the two years prior to TB diagnosis more frequently $(50.5 \%)$ than did Mexican-born border TB patients $(37.5 \%)$ and Mexican-born nonborder TB patients $(21.1 \%)\left(\chi^{2}, P<\right.$ 0.001 for both comparisons).

Higher drug-resistance rates were noted among isolates from Mycobac- 
TABLE 2. Basic characteristics among tuberculosis (TB) cases for the three comparison groups, United States (U.S.), 1993-2001

\begin{tabular}{|c|c|c|c|c|c|c|}
\hline \multirow[b]{2}{*}{ Characteristic } & \multicolumn{2}{|c|}{ Mexican-born border ${ }^{a}$} & \multicolumn{2}{|c|}{ U.S.-born border ${ }^{\text {b }}$} & \multicolumn{2}{|c|}{ Mexican-born nonborder ${ }^{c}$} \\
\hline & No. & $\%$ & No. & $\%$ & No. & $\%$ \\
\hline Gender & 12450 & 100.0 & 25508 & 100.0 & 3773 & 100.0 \\
\hline Female & 4367 & 35.1 & 8305 & 32.6 & 1174 & 31.1 \\
\hline Unknown & 0 & 0.0 & 9 & $<0.1$ & 0 & 0.0 \\
\hline $15-24$ & 1821 & 14.6 & 1540 & 6.0 & 901 & 23.9 \\
\hline $25-44$ & 4911 & 39.4 & 8572 & 33.6 & 1734 & 46.0 \\
\hline $45-64$ & 2863 & 23.0 & 7152 & 28.0 & 639 & 16.9 \\
\hline $65+$ & 1985 & 15.9 & 5024 & 19.7 & 259 & 6.9 \\
\hline Unknown & 2 & $<0.1$ & 2 & $<0.1$ & 0 & 0.0 \\
\hline Site of disease & 12450 & 100.0 & 25508 & 100.0 & 3773 & 100.0 \\
\hline \multicolumn{7}{|l|}{ Sputum smear for } \\
\hline acid fast bacillid $\left.{ }^{\text {(adults }}{ }^{\mathrm{e}}\right)$ & 9766 & 100.0 & 19055 & 100.0 & 2855 & 100.0 \\
\hline Positive & 5076 & 52.0 & 8759 & 46.0 & 1605 & 56.2 \\
\hline Negative & 3980 & 40.8 & 7645 & 40.1 & 1070 & 37.5 \\
\hline Unknown ${ }^{\dagger}$ & 710 & 7.3 & 2651 & 13.9 & 180 & 6.3 \\
\hline Sputum culture ${ }^{\mathrm{d}}\left(\right.$ adults $\left.^{\mathrm{e}}\right)$ & 9766 & 100.0 & 19055 & 100.0 & 2855 & 100.0 \\
\hline Mycobacterium tuberculosis-positive & 7526 & 77.1 & 14174 & 74.4 & 2221 & 77.8 \\
\hline Mycobacterium tuberculosis-negative & 1524 & 15.6 & 2486 & 13.0 & 441 & 15.5 \\
\hline Unknown ${ }^{\dagger}$ & 716 & 7.3 & 2395 & 12.6 & 193 & 6.8 \\
\hline Chest radiograph ${ }^{d}$ & 10425 & 100.0 & 21504 & 100.0 & 3039 & 100.0 \\
\hline Normal & 212 & 2.0 & 662 & 3.1 & 95 & 3.1 \\
\hline \multicolumn{7}{|l|}{ HIV status among TB patients } \\
\hline aged $25-44$ yrs old ${ }^{h}$ & 4411 & 100.0 & 8036 & 100.0 & 1461 & 100.0 \\
\hline Positive & 648 & 14.7 & 2504 & 31.2 & 165 & 11.3 \\
\hline Negative & 561 & 12.7 & 1287 & 16.0 & 740 & 50.7 \\
\hline Unknown ${ }^{\dagger}$ & 3202 & 72.6 & 4245 & 52.8 & 556 & 38.1 \\
\hline Reason therapy was stopped ${ }^{i, j}$ & 9655 & 100.0 & 20597 & 100.0 & 2589 & 100.0 \\
\hline Completed therapy & 7849 & 81.3 & 16500 & 80.1 & 2043 & 78.9 \\
\hline \multicolumn{7}{|l|}{ Did not complete therapy } \\
\hline Moved & 754 & 7.8 & 686 & 3.3 & 265 & 10.2 \\
\hline Lost & 353 & 3.7 & 768 & 3.7 & 149 & 5.8 \\
\hline Died & 584 & 6.0 & 2335 & 11.4 & 85 & 3.3 \\
\hline Other/Unknown & 115 & 1.2 & 308 & 1.5 & 47 & 1.8 \\
\hline $\begin{array}{l}\text { a Mexican-born border }=\text { TB cases among Mexica } \\
\text { b U.S.-born border = TB cases among U.S.-born } \\
\text { c Mexican-born nonborder = TB cases among Me } \\
\text { d Includes only persons with pulmonary TB. } \\
\text { e Adult is defined as a person aged } \geq 15 \text { years. } \\
\text { f Unknown includes "Not done" and "Unknown." } \\
\text { g Percentage is among those with an abnormal ch } \\
\text { h Includes only TB cases reported between } 1993 \\
\text { i Includes only TB cases reported between } 1993 \\
\text { j Includes only persons with TB who were alive a }\end{array}$ & graph. & in th & that a & $\begin{array}{l}\text { kas). } \\
\text { er with }\end{array}$ & & \\
\hline
\end{tabular}


TABLE 3. Sociodemographic characteristics ${ }^{\mathrm{a}}$ among tuberculosis (TB) cases aged 18 to 64 years for the three comparison groups, United States (U.S.), 1993-2001

\begin{tabular}{|c|c|c|c|c|c|c|c|c|c|}
\hline \multirow[b]{3}{*}{ Characteristic } & \multirow{2}{*}{\multicolumn{2}{|c|}{$\begin{array}{l}\text { Mexican-born } \\
\text { border }^{c}\end{array}$}} & \multirow{2}{*}{\multicolumn{2}{|c|}{$\begin{array}{l}\text { U.S.-born } \\
\text { border }^{b}\end{array}$}} & \multirow{2}{*}{\multicolumn{2}{|c|}{$\begin{array}{l}\text { Mexican-born } \\
\text { nonborder }^{d}\end{array}$}} & \multicolumn{2}{|c|}{ U.S.-born border ${ }^{\text {b }}$} & \multirow{3}{*}{$\begin{array}{c}\begin{array}{c}\text { MX-born } \\
\text { borderc }^{c}\end{array} \\
\text { MX-b nb }{ }^{d, g} \\
R^{h} \\
(95 \% \mathrm{Cl})^{\mathrm{i}}\end{array}$} \\
\hline & & & & & & & \multirow{2}{*}{$\frac{M X-b b^{c, e}}{R^{h}}$} & \multirow{2}{*}{$\frac{\text { MX-b nb } b^{d, f}}{R^{h}}$} & \\
\hline & No. & $\%$ & No. & $\%$ & No. & $\%$ & & & \\
\hline Total & 9365 & 100.0 & 16934 & 100.0 & 3185 & 100.0 & & & \\
\hline \multicolumn{10}{|c|}{$\begin{array}{l}\text { Within past year of TB diagnosis } \\
\text { Homeless }\end{array}$} \\
\hline $\begin{array}{l}\text { Yes } \\
\text { No } \\
\text { Unknown }\end{array}$ & $\begin{array}{r}621 \\
8249 \\
495\end{array}$ & $\begin{array}{r}6.6 \\
88.1 \\
5.3\end{array}$ & $\begin{array}{r}2709 \\
13645 \\
580\end{array}$ & $\begin{array}{r}16.0 \\
80.6 \\
3.4\end{array}$ & $\begin{array}{r}203 \\
2753 \\
229\end{array}$ & $\begin{array}{r}6.4 \\
86.4 \\
7.2\end{array}$ & $\begin{array}{c}2.4 \\
(2.2,2.6)\end{array}$ & $\begin{array}{c}2.4 \\
(2.1,2.8)\end{array}$ & $\begin{array}{c}1.0 \\
(0.9,1.2)\end{array}$ \\
\hline $\begin{array}{l}\text { Noninjecting drug use } \\
\text { Yes } \\
\text { No } \\
\text { Unknown }\end{array}$ & $\begin{array}{r}599 \\
7583 \\
1183\end{array}$ & $\begin{array}{r}6.4 \\
81.0 \\
12.6\end{array}$ & $\begin{array}{r}2440 \\
12293 \\
2201\end{array}$ & $\begin{array}{l}14.4 \\
72.6 \\
13.0\end{array}$ & $\begin{array}{r}97 \\
2547 \\
541\end{array}$ & $\begin{array}{r}3.0 \\
80.0 \\
17.0\end{array}$ & $\begin{array}{c}2.3 \\
(2.1,2.5)\end{array}$ & $\begin{array}{c}4.5 \\
(3.7,5.5)\end{array}$ & $\begin{array}{c}2.0 \\
(1.6,2.5)\end{array}$ \\
\hline $\begin{array}{l}\text { Excess alcohol use } \\
\text { Yes } \\
\text { No } \\
\text { Unknown }\end{array}$ & $\begin{array}{l}1506 \\
6764 \\
1095\end{array}$ & $\begin{array}{l}16.1 \\
72.2 \\
11.7\end{array}$ & $\begin{array}{r}4218 \\
10860 \\
1856\end{array}$ & $\begin{array}{l}24.9 \\
64.1 \\
11.0\end{array}$ & $\begin{array}{r}389 \\
2296 \\
500\end{array}$ & $\begin{array}{l}12.2 \\
72.1 \\
15.7\end{array}$ & $\begin{array}{c}1.5 \\
(1.5,1.6)\end{array}$ & $\begin{array}{c}1.9 \\
(1.8,2.1)\end{array}$ & $\begin{array}{c}1.3 \\
(1.1,1.4)\end{array}$ \\
\hline $\begin{array}{l}\text { Occupation within past } 2 \\
\text { TB diagnosis } \\
\text { Not employed } \\
\text { Health care worker } \\
\text { Correctional employee } \\
\text { Migratory/agriculture } \\
\text { Other } \\
\text { Multiple occupations } \\
\text { Unknown }\end{array}$ & $\begin{array}{r}3516 \\
84 \\
1 \\
680 \\
3817 \\
11 \\
1256\end{array}$ & $\begin{array}{r}37.5 \\
0.9 \\
<0.1 \\
7.3 \\
40.8 \\
0.1 \\
13.4\end{array}$ & $\begin{array}{r}8556 \\
481 \\
61 \\
84 \\
4816 \\
11 \\
2925\end{array}$ & $\begin{array}{r}50.5 \\
2.8 \\
0.4 \\
0.5 \\
28.4 \\
0.1 \\
17.3\end{array}$ & $\begin{array}{r}673 \\
16 \\
0 \\
489 \\
1619 \\
15 \\
373\end{array}$ & $\begin{array}{r}21.1 \\
0.5 \\
0.0 \\
15.4 \\
50.8 \\
0.5 \\
11.7\end{array}$ & $\begin{array}{c}1.4 \\
(1.4,1.5)\end{array}$ & $\begin{array}{c}2.6 \\
(2.4,2.7)\end{array}$ & $\begin{array}{c}1.8 \\
(1.7,1.9)\end{array}$ \\
\hline
\end{tabular}

terium tuberculosis culture-positive Mexican-born border and nonborder TB patients as compared to United States-born border TB patients (Table 4). This was especially true among patients with a prior history of TB disease. Among patients without a prior history of TB, $16.7 \%$ of Mexican-born border, $15.9 \%$ of Mexican-born nonborder, and $9.4 \%$ of United States-born border TB patients had isolates resistant to at least one first-line drug (i.e., isoniazid, rifampin, ethambutol, pyrazinamide, streptomycin). In addition, there were significantly increased rates among persons with a prior his- tory of TB. Within each border state in the United States, $13.6 \%-22.8 \%$ of TB cases caused by organisms resistant to at least one first-line drug were reported from a border county.

Drug resistance also varied by the number of years a TB patient had resided in the United States (Table 5). 
TABLE 4. Drug resistance among culture-positive tuberculosis (TB) cases for the three comparison groups, United States (U.S.), 1993-2001

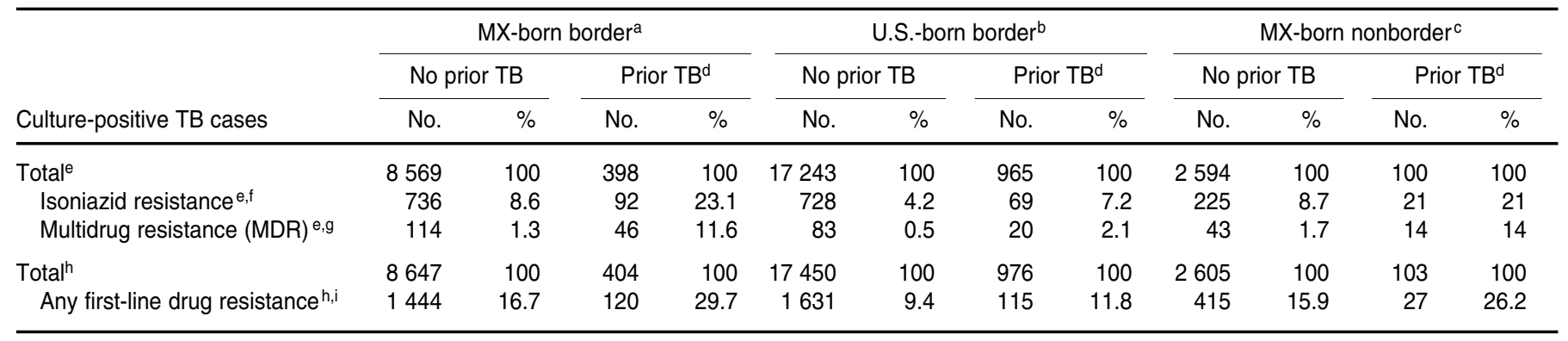

${ }^{a}$ Mexican-born border (MX-born border) = TB cases among Mexican-born persons from the four U.S. border states (Arizona, California, New Mexico, Texas).

${ }^{b}$ U.S.-born border $=$ TB cases among U.S.-born persons from the four U.S. border states (Arizona, California, New Mexico, Texas).

${ }^{c}$ Mexican-born nonborder (MX-born nonborder) = TB cases among Mexican-born persons from the 46 U.S. states not on the border with Mexico.

d Prior TB: a person with TB was considered to have had a prior episode of TB if TB was verified in the past and the person completed therapy or was lost to supervision for more than 12 consecutive months.

e Culture-positive for Mycobacterium tuberculosis with initial susceptibility testing done for isoniazid and rifampin.

${ }^{\mathrm{f}}$ Isoniazid resistance $=$ resistance to at least isoniazid.

9 Multidrug resistance $(\mathrm{MDR})=$ resistance to at least isoniazid and rifampin.

${ }^{\mathrm{h}}$ Culture-positive for Mycobacterium tuberculosis with initial susceptibility testing done for isoniazid, rifampin, ethambutol, pyrazinamide, or streptomycin.

i Any first-line drug resistance = resistance to at least isoniazid, rifampin, ethambutol, pyrazinamide, or streptomycin.

Isoniazid (INH) resistance among Mexican-born border TB patients was more frequently seen within the first year of arrival to the United States than was true for either Mexican-born nonborder TB patients or other foreign-born TB patients from the border states. Multidrug resistance (MDR) was more often diagnosed within the first year of arrival for all comparison groups.

Multivariate analysis revealed that among pulmonary TB patients 18 to 64 years of age, Mexican-born border TB patients were 3.6 times as likely to have MDR TB as were United Statesborn border TB patients (Table 6). Those patients with at least one prior episode of TB were approximately 8 times as likely to have MDR TB as were those experiencing their first episode of TB. Other significant positive associations with MDR TB included the presence of cavitary and smear-positive disease at diagnosis. Reported excess alcohol use in the past year was negatively associated with MDR TB.

Analysis of risk factors for resistance to INH revealed that Mexican-born border TB patients were approximately two times as likely to have INH resistance as were United States-born border patients (Table 7). Those who had had a previous episode of TB were also about two times as likely to have INHresistant disease. In contrast to MDR $\mathrm{TB}$, significant positive risk factors for INH-resistant TB included being a correctional facility employee within the past two years, and residing (as an inmate) in a correctional facility at the time of diagnosis. Similar to MDR TB, the presence either of smear positivity or of cavitary disease at diagnosis was

TABLE 5. Primary drug resistance by years of residence in the United States among adult culture-positive tuberculosis (TB) cases ${ }^{\text {a for the }}$ three comparison groups, United States (U.S.), 1993-2001

\begin{tabular}{|c|c|c|c|c|c|c|c|c|c|c|c|c|c|c|c|}
\hline \multirow{3}{*}{$\begin{array}{c}\text { Years in U.S. } \\
\text { prior to TB } \\
\text { diagnosis }^{f}\end{array}$} & \multicolumn{5}{|c|}{ Mexican-born border ${ }^{b}$} & \multicolumn{5}{|c|}{ Other-FB border ${ }^{\mathrm{C}}$} & \multicolumn{5}{|c|}{ Mexican-born nonborder ${ }^{d}$} \\
\hline & \multirow{2}{*}{ No. } & \multicolumn{4}{|c|}{ Resistance } & \multicolumn{5}{|c|}{ Resistance } & \multirow{2}{*}{ No. } & \multicolumn{4}{|c|}{ Resistance } \\
\hline & & \multicolumn{2}{|c|}{ Isoniazid } & \multicolumn{2}{|c|}{$\mathrm{MDR}^{\mathrm{e}}$} & No. & \multicolumn{2}{|c|}{ Isoniazid } & \multicolumn{2}{|c|}{$\mathrm{MDR}^{\mathrm{e}}$} & & \multicolumn{2}{|c|}{ Isoniazid } & \multicolumn{2}{|c|}{$\mathrm{MDR}^{\mathrm{e}}$} \\
\hline$<1$ & 1129 & 128 & 11.3 & 38 & 3.4 & 2474 & 358 & 14.5 & 59 & 2.4 & 518 & 45 & 8.7 & 13 & 2.5 \\
\hline 1 to 4 & 1398 & 122 & 8.7 & 23 & 1.6 & 2688 & 416 & 15.5 & 53 & 2.0 & 699 & 50 & 7.2 & 7 & 1.0 \\
\hline
\end{tabular}

a Includes adult (i.e., $\geq 15$ years) TB cases, without a prior history of TB, who were culture-positive for Mycobacterium tuberculosis with initial susceptibility testing done for isoniazid and rifampin.

${ }^{\mathrm{b}}$ Mexican-born border $=$ TB cases among Mexican-born persons from the four U.S. border states (Arizona, California, New Mexico, Texas).

${ }^{c}$ Other foreign-born border (Other-FB border) includes only foreign-born (FB) persons with TB who were born in countries other than Mexico and reported from the four U.S. border states (Arizona, California, New Mexico, Texas).

${ }^{\mathrm{d}}$ Mexican-born nonborder = TB cases among Mexican-born persons from the 46 U.S. states not on the border with Mexico.

e Multidrug resistance (MDR) = resistance to at least isoniazid and rifampin.

${ }^{f}$ Years in U.S. prior to TB diagnosis $=$ number of years a TB case resided in the U.S. prior to TB diagnosis. 
TABLE 6. Multivariate analysis of risk factors for multidrug resistance among 17936 Mexican-born and United States-born pulmonary tuberculosis (TB) patients in the four United States border states ${ }^{\mathrm{a}}, 1993-2001$

\begin{tabular}{lrrcc}
\hline \multicolumn{1}{c}{ Risk factor } & No. & $\%^{\mathrm{b}}$ & Odds ratio & ${ }^{\circ} \% \mathrm{Cl}^{\mathrm{c}}$ \\
\hline Mexican-born & 6222 & 34.7 & 3.6 & $2.6-5.1$ \\
History of previous TB disease & 902 & 5.0 & 8.2 & $5.7-11.7$ \\
Male & 13209 & 73.7 & 0.96 & $0.68-1.4$ \\
Age (years) & & & & \\
$\quad 18-24$ & 1902 & 10.6 & 1.3 & $0.81-2.0$ \\
$25-44$ & 9140 & 51.0 & 0.96 & $0.68-1.4$ \\
$\quad 65-64$ & 6894 & 38.4 & Ref & - \\
Excess alcohol use within past year $^{\mathrm{d}}$ & 4499 & 28.1 & 0.58 & $0.38-0.88$ \\
Cavitary disease at diagnosis $^{\mathrm{e}}$ & 5639 & 37.7 & 1.9 & $1.4-2.7$ \\
Sputum smear-positive for AFB at diagnosis $^{\mathrm{f}}$ & 10522 & 63.8 & 1.5 & $1.0-2.2$ \\
\hline
\end{tabular}

a Includes only persons 18-64 years old, with pulmonary TB, confirmed culture-positive for Mycobacterium tuberculosis, with initial susceptibility testing done for isoniazid and rifampin, and for whom country of birth and previous TB status were known. Multidrug resistance is defined as resistance to at least isoniazid and rifampin.

${ }^{b}$ Percents reflect exclusion of unknowns.

c $95 \% \mathrm{Cl}=95 \%$ confidence interval.

${ }^{d}$ Determined using a combination of self-report and medical documentation (22).

${ }^{e}$ Cavitary disease at diagnosis $=$ cavitary disease on initial chest radiograph

${ }^{f} \mathrm{AFB}=$ acid fast bacilli.

TABLE 7. Multivariate analysis of risk factors for isoniazid resistance among 17936 Mexican-born and United States-born pulmonary tuberculosis (TB) patients in the four United States border states ${ }^{\mathrm{a}}, 1993-2001$

\begin{tabular}{|c|c|c|c|c|}
\hline Risk factor & No. & $\%^{\mathrm{b}}$ & Odds ratio & $95 \% \mathrm{Cl}^{\mathrm{c}}$ \\
\hline Mexican-born & 6222 & 34.7 & 2.2 & $1.9-2.5$ \\
\hline History of previous TB disease & 902 & 5.0 & 2.2 & $1.7-2.9$ \\
\hline Male & 13209 & 73.7 & 0.96 & $0.81-1.1$ \\
\hline \multicolumn{5}{|l|}{ Age (years) } \\
\hline $\begin{array}{l}18-24 \\
25-44 \\
45-64\end{array}$ & $\begin{array}{l}1902 \\
9140 \\
6894\end{array}$ & $\begin{array}{l}10.6 \\
51.0 \\
38.4\end{array}$ & $\begin{array}{l}1.1 \\
1.2 \\
\text { Ref }\end{array}$ & $\begin{array}{c}0.85-1.4 \\
0.99-1.4 \\
-\end{array}$ \\
\hline Homeless within past year ${ }^{d}$ & 2582 & 14.9 & 0.71 & $0.56-0.90$ \\
\hline In correctional facility at diagnosis ${ }^{d}$ & 1997 & 11.2 & 1.3 & $1.0-1.6$ \\
\hline Cavitary disease at diagnosis ${ }^{e}$ & 5639 & 37.7 & 1.2 & $1.0-1.4$ \\
\hline Sputum smear-positive for AFB at diagnosis ${ }^{\dagger}$ & 10522 & 63.8 & 1.3 & $1.1-1.5$ \\
\hline \multicolumn{5}{|l|}{ Occupationg } \\
\hline Unemployed & 8381 & 54.8 & 0.85 & $0.73-0.99$ \\
\hline Health care worker & 360 & 2.4 & 0.86 & $0.48-1.5$ \\
\hline Correctional facility & 32 & 0.21 & 3.6 & $1.2-10.7$ \\
\hline Migratory agricultural worker & 534 & 3.5 & 1.2 & $0.92-1.7$ \\
\hline Multiple occupations & 15 & 0.10 & 0.93 & $0.12-7.4$ \\
\hline Other occupations combined & 5970 & 39.0 & Ref & - \\
\hline
\end{tabular}

a Includes only persons 18-64 years old, with pulmonary TB, confirmed culture-positive for Mycobacterium tuberculosis, with initial susceptibility testing done for isoniazid and rifampin, and for whom country of birth and previous TB status were known.

b Percents reflect exclusion of unknowns.

c $95 \% \mathrm{Cl}=95 \%$ confidence interval.

${ }^{\mathrm{d}}$ Determined using a combination of self-report and medical documentation (22).

e Cavitary disease at diagnosis = cavitary disease on initial chest radiograph.

${ }^{f} \mathrm{AFB}=$ acid fast bacilli.

9 Occupation = occupation in the two years prior to TB diagnosis. positively associated with INH-resistant TB. Having been either unemployed within the past two years or homeless within the past year was negatively associated with INH-resistant TB.

A similar analysis among just Mexican-born pulmonary TB patients and their geographic location within the United States (i.e., border state vs. nonborder state) revealed that geographic location was not an independent risk factor for MDR or INH-resistant TB. However, among Mexican-born TB patients, being unemployed in the two years prior to diagnosis (odds ratio $(\mathrm{OR})=1.9 ; 95 \% \mathrm{CI}, 1.3-2.7)$ and reported excess alcohol use in the past year $(\mathrm{OR}=0.45 ; 95 \% \mathrm{CI}, 0.27-0.76)$ were associated (positively and negatively, respectively) with MDR TB, controlling for geographic location, history of previous TB, age, sex, and cavitary disease. Further, being HIV-positive was significantly negatively associated with INH resistance $(\mathrm{OR}=0.52$; $95 \% \mathrm{CI}, 0.35$ $0.75)$, controlling for geographic location, history of previous $\mathrm{TB}$, age, sex, cavitary disease, and smear-positivity.

In 1999 the proportion of Mexicanborn border TB patients $(84.0 \%)$ who received at least some anti-TB treatment using directly observed therapy (DOT) was slightly greater than for Mexican-born nonborder patients $(83.2 \%)$ and for United States-born patients (79.7\%). In 1999, completion of therapy was similar for all comparison groups (United States-born border: 85.6\%; Mexican-born border: $84.4 \%$; Mexican-born nonborder: 84.1\%). From 1993 through 1999, the most commonly reported reasons for stopping therapy, other than completing therapy, included moving, being lost to follow-up, and having died (any cause). Mexican-born TB patients were significantly more likely to have moved or be lost to follow-up as a final outcome than were United States-born border-state TB patients (Table 2). This was true both for Mexican-born TB patients in the border states $(\mathrm{RR}=$ 1.6; $95 \%$ CI, 1.5-1.8) and ones in the nonborder states $(\mathrm{RR}=2.3 ; 95 \% \mathrm{CI}$, 2.1-2.5). More United States-born TB 
border-state patients died (any cause) during therapy $(11.3 \%)$ than did Mexican-born TB patients, in both the border states (6.1\% died) and the nonborder states $(3.3 \%$ died). In all three of those comparison groups, between one-quarter and one-third of the TB patients who died (any cause) before completing therapy were HIV-infected (Mexican-born border: 26.9\%; Mexican-born nonborder: $28.2 \%$; United States-born border: $32.1 \%$ ).

\section{DISCUSSION}

To our knowledge, this is the first published analysis that uses data collected at the national level in the United States to make comparisons among Mexican-born border-state TB patients, United States-born borderstate TB patients, and Mexican-born nonborder-state TB patients. The importance of this description can be highlighted by the fact that Mexico contributes the largest number and the largest proportion of foreign-born TB patients towards the total annual TB morbidity in the United States. Further, the four states in the United States that border Mexico account for the majority of the TB cases in Mexican-born persons in the United States. The overall TB case rate for Mexican-born persons in these four border states was five times as great as the rate for United States-born persons in these states. Importantly, the case rates for Mexican-born TB patients in the 46 nonborder states were also elevated compared to United States-born rates from the four border states and were also very similar to rates for Mexicanborn patients reported from the border states. That was true even though there were fewer Mexican-born nonborder TB cases than there were Mexican-born border and United States-born border cases. Interestingly, among United States-born TB cases in California and Texas, case rates were elevated among persons living in the border counties as compared to the overall state TB case rate. These higher case rates may reflect risk associated with family immi- gration patterns or travel history (28), or they may also reflect ongoing TB transmission along the border.

Among adult pulmonary TB cases, those in Mexican-born persons more frequently were sputum smear-positive and had evidence of cavitary disease on chest radiograph than was true for United States-born TB patients. This finding may indicate more extensive disease progression prior to TB diagnosis among Mexican-born TB patients. The reasons for this finding are unclear, but they may be related to more limited access to care or to a delay in seeking or obtaining care (29). These factors may prolong infectiousness and contribute to ongoing transmission within the community. Timely access to care is important for interrupting the transmission chain in this population. Unique to Mexicanborn border-state TB patients was the longer amount of time spent in the United States prior to TB diagnosis (e.g., at least five years) compared to Mexican-born nonborder-state patients and to border-state TB patients who had been born in countries other than Mexico. This longer period before diagnosis may be related to residing longer in the United States and/or an increased opportunity for frequent border crossings between the United States and country of birth for persons living along the United States-Mexico border.

Specific risk factors, such as drug and alcohol use, incarceration, and unemployment, were less likely to be reported in Mexican-born TB patients than in United States-born patients. The most important risk factor for the Mexican-born TB patients appears to be birth in a country with a relatively high incidence of TB. HIV coinfection was more commonly reported among United States-born border-state TB patients than among Mexican-born TB patients. However, our analysis also revealed that HIV test results are not reported to the national TB surveillance system for a large proportion of TB patients despite the recommendation that all TB cases receive HIV counseling and testing (30). Possible expla- nations for this deficient reporting include health providers not performing HIV counseling and testing or not reporting the HIV test results, as well as the existence of local confidentiality directives that restrict the reporting of HIV test results. To properly identify TB-HIV coinfected patients and ensure appropriate therapy, all TB patients, independent of age or HIV risk factors, should receive $\mathrm{HIV}$ counseling and testing once TB disease is diagnosed (31).

Mexican-born TB patients were almost four times as likely to have MDR $\mathrm{TB}$ and twice as likely to have INH resistance as their United States-born counterparts, even after controlling for a previous history of TB. Among Mexican-born TB patients, location with respect to the United States-Mexico border was not a risk factor for either MDR TB or INH resistance. Therefore, the finding of drug resistance among Mexican-born TB patients who have recently arrived in the United States may reflect transmission of drug-resistant TB in Mexico prior to arrival. In a continued effort to address TB drug resistance, especially MDR TB, the Mexican National TB Program (Programa de Acción Tuberculosis) plans to conduct a national drug resistance survey to determine the current prevalence of drug resistance and to initiate a DOTS-Plus project with drugs purchased through the Green Light Committee of the World Health Organization $(32,33)$. Currently, partial assistance for drug-resistant TB patients is provided through binational TB projects located along the United StatesMexico border. A priority for these binational projects has been the identification and case management of patients with MDR TB by providing second-line anti-TB drugs, laboratory support (e.g., drug susceptibility testing), and outreach workers to ensure treatment adherence and to conduct contact investigations. Management of drug resistance in all of Mexico and in the United States along its border with Mexico is crucial for preventing the transmission of drug-resistant TB in the United States. 
Currently, the national TB surveillance system in the United States does not collect information on binational status (34), immigration status, or, for pediatric TB patients, their travel history or the country of birth of their parents/guardians. To better capture this information, a workgroup of local, state, and national TB surveillance experts from the United States has proposed a revision of the case report, which is expected to be implemented in 2006 or later. The proposed changes to the national TB surveillance system in the United States would allow counties and states to more easily collect data on TB patients who are not officially counted in the annual morbidity totals for the country. In the United States, many border counties and states now provide care for $\mathrm{TB}$ patients that they cannot count towards their annual morbidity totals because these cases were or should have been counted elsewhere (e.g., Mexico) (2). These "uncounted" patients often receive extensive care in the United States, thus placing the burden for treatment, care, and contact investigations on local TB control programs. Proposed changes to the national TB surveillance system in the United States would enhance characterization of such TB patients as well as permit measurement of the burden, thus allowing local TB control programs to substantiate the need for additional funding and resources.

Despite the recent success against TB in the United States, control of TB along the United States-Mexico border remains challenging. During the study period, Mexican-born TB patients were almost twice as likely to have moved during therapy or to be lost to follow-up as were United States-born TB patients. This finding, combined with the fact that the population on both sides of the United States-Mexico border is highly mobile, has attracted the attention of the federal Governments of both Mexico and the United States and has resulted in an innovative new binational initiative, the U.S.Mexico Binational TB Referral and Case Management Project. That proj- ect tracks and manages binational patients with active TB disease who cross the United States-Mexico border. ${ }^{3}$ The project's main objectives are to ensure continuity of care and treatment completion, thus preventing further $\mathrm{TB}$ transmission and the emergence of drug resistance. This project, which is the product of a collaboration among the local, state, and federal levels of both Mexico and the United States, is piloting an integrated system that uses a binational health card and a binational referral network in three sites in the United States and ten sites in Mexico. (The binational health card is a wallet-sized card in both English and Spanish that has a unique identification number that links the card to the TB patient and the patient's TB information in two national databases as well as toll-free telephone contact numbers in the United States and Mexico where a patient or provider can call for necessary information to assure continuity of TB care.) This new project is building upon and integrating the efforts of two well-established programs, CureTB (20) and TBNet (21), and for the first time linking their referral services directly with a similar effort by the Mexican National TB Program. The Bureau of Immigration and Customs Enforcement of the United States, through its detention centers in the cities of El Paso, Texas, and San Diego, California, is also participating in order to facilitate continuity of care for immigration-law violators who are being returned to Mexico. If this binational TB project proves successful and cost-effective, plans include expansion to all TB patients in the United States and Mexico who cross the border. TB control efforts among the Mexicanborn population in the United States and Mexico-many of whom in the

\footnotetext{
3 Laserson KF, Ferreira E, Ortega L, Burns A, Escobedo M, Moser K, et al. Development of a binational tuberculosis information system of case management [poster presentation]. US-Mexico Border Health Association Meeting. Chihuahua, Chihuahua, Mexico, June 2002.
}

United States are undocumented and for whom accessing services is difficult-will need to rely on creative initiatives such as these.

The impact of TB among Mexicanborn persons extends far beyond the United States-Mexico border, affecting TB control throughout the United States and Mexico. Binational local and federal public health action is essential for TB control and prevention in this distinctive region, the United States-Mexico border (35). Continued United States-Mexico collaboration and dedication of necessary resources are critical to the identification, successful treatment, and prevention of TB along the border.

Acknowledgements. This work was funded by the Division of Tuberculosis Elimination of the United States Centers for Disease Control and Prevention. We would like to thank the state and local tuberculosis control officials in health departments throughout the United States who collected and reported the national surveillance data presented in this paper; the surveillance staff at the Division of Tuberculosis Elimination, Centers for Disease Control and Prevention (CDC) who maintain the national database; and the Dirección General de Epidemiología, Secretaría de Salud for sharing 2001 TB data from the Mexican states that border the United States. Additionally, we would like to thank the following individuals for their critical review of this manuscript: Edith Elizabeth Ferreira Guerrero, Director of the National Tuberculosis Program, Mexico; Kenneth G. Castro, Director, Division of Tuberculosis Elimination, CDC; Jose Becerra, Chief, Information Technology and Statistics Branch, Division of Tuberculosis Elimination, CDC; Miguel A. Escobedo, Regional Director Public Health Region 9/10, Texas Department of Health; Deliana Garcia, Director, International Research and Development, Migrant Clinicians Network, Inc.; Fernando J. Gonzalez, Director, Binational Tuberculosis Prevention and Control Project "JUNTOS"; Michael F. Iademarco, Associate Director 
for Science, Division of Tuberculosis Elimination, CDC; Cheryl McRill, State Tuberculosis Control Officer, Arizona Department of Health Services; Kathleen Moser, Director, Tuberculosis Control Program, San Diego County Health and Human Services Agency; Eva M. Moya, Executive Director, United States Section, United StatesMexico Border Health Commission;
Thomas R. Navin, Chief, Surveillance, Epidemiology, and Outbreak Investigations Branch, Division of Tuberculosis Elimination, CDC; Luis Ortega, Office of the State Epidemiologist, Texas Department of Health; Sarah Royce, Chief, Tuberculosis Control Branch, California Department of Health Services; Gary L. Simpson, Medical Director, Infectious Diseases, New Mexico
Department of Health; Zachary Taylor, Chief, Field Services and Evaluation Branch, Division of Tuberculosis Elimination, CDC; Charles E. Wallace, Director, Tuberculosis Elimination Division, Texas Department of Health; and Stephen Waterman, Medical Epidemiologist, Division of Tuberculosis Elimination and Division of Global Migration and Quarantine, CDC.

\section{REFERENCES}

1. United States-Mexico Border Health Commission. 2001 annual report of the United StatesMexico Border Health Commission. Washington D.C.: USMBHC; 2002.

2. United States, Centers for Disease Control and Prevention. Reported tuberculosis in the United States, 2001. Atlanta: United States Department of Health and Human Services, CDC; 2002.

3. International Boundary and Water Commission. International Boundary and Water Commission [Web site]. Available from: http:// www.ibwc.state.gov/html/about_us.html. Accessed 1 July 2004

4. United States Department of Transportation, Bureau of Transportation Statistics. Border crossing/entry data. Available from: http:// www.bts.gov/programs/international/ border_crossing_entry_data/. Accessed 1 July 2004.

5. Granich RM, Balandrano S, Santaella AJ, Binkin NJ, Castro KG, Marquez-Fiol A, et al. Survey of drug resistance of Mycobacterium tuberculosis in 3 Mexican states, 1997. Arch Intern Med. 2000;160:639-44.

6. Granich RM, Moore M, Binkin NJ, McCray E. Drug-resistant tuberculosis in foreign-born persons from Mexico, the Philippines, and Vietnam-United States, 1993-1997. Int J Tuberc Lung Dis. 2001;5(1):53-8.

7. Taylor JP, Suarez L. Prevalence and risk factors of drug-resistant tuberculosis along the Mexico-Texas border. Am J Public Health. 2000;90: 271-3.

8. Taylor JP, Bergmire-Sweat D, Suarez L. Epidemiology of drug-resistant tuberculosis in Texas. Am J Epidemiol. 1999;149:359-65.

9. Quitugua TN, Seaworth BJ, Weis SE, Taylor JP, Gillette JS, Rosas II, et al. Transmission of drug-resistant tuberculosis in Texas and Mexico. J Clin Microbiol. 2002;40:2716-24.

10. Burman WJ. Worrisome news from Mexico: drug resistance and DNA fingerprinting. Int J Tuberc Lung Dis. 2001;5(4):299-300.

11. Schulte JM, Valway SE, McCray E, Onorato IM. Tuberculosis cases reported among mi- grant farm workers in the United States, 1993-1997. J Health Care Poor Underserved. 2001;12(3):311-22.

12. Weis SE, Burgess G. Tuberculosis control in a border state. Inf Dis Clin N Amer. 2002;16(1): 59-71.

13. Weis SE, Moonan PK, Pogoda JM, Turk L, King B, Freeman-Thompson S, et al. Tuberculosis in the foreign-born population of Tarrant County, Texas by immigration status. Am J Respir Crit Care Med. 2001;164:953-7.

14. United States, Census Bureau. Number of foreign-born up 57 percent since 1990, according to Census 2000 [press release]. Census Bureau News. 4 June 2002. (CB02-CN.117).

15. Pan American Health Organization. On the United States-Mexico border, cooperation is the word [press release]. Washington, D.C.: PAHO; 2002. (Centennial News and Information).

16. United States, Department of Health and Human Services, Health Resources and Services Administration. HRSA's Border Health Program (October 2001). Available from: http://newsroom.hrsa.gov/factsheets/border health2001.htm. Accessed 1 July 2004.

17. United States Agency for International Development. Mexico. Activity data sheet. Sustainable and effective institutional capacity developed to diagnose, control, and monitor tuberculosis in target areas, 523-008. Available from: http://www.usaid.gov/pubs/ cbj2002/lac/mx/523-008.html. Accessed 1 July 2004.

18. The Robert Wood Johnson Foundation. A model for cooperation: US-Mexico tuberculosis control. National program project report 1997. Available from: http://www.rwjf. org/reports/grr/023612.htm. Accessed 1 July 2004.

19. United States, Centers for Disease Control and Prevention. CDC's response to ending neglect: the elimination of tuberculosis in the United States. Atlanta: United States Department of Health and Human Services, CDC; 2002.
20. County of San Diego, Health and Human Services Agency. CureTB: binational TB referral program. Available from: http:/ / www. curetb. org. Accessed 1 July 2004.

21. Migrant Clinicians Network. TBNet. Available from: http://www.migrantclinician. org/programs/TBNet/tb.html. Accessed 1 July 2004.

22. United States, Centers for Disease Control and Prevention, Division of Tuberculosis Elimination. Tuberculosis Information Management System (TIMS) user's guide. Atlanta: CDC; 1998.

23. United States, Census Bureau. Profile of the foreign-born population in the United States: 2000. Washington, D.C.: United States Government Printing Office; 2001. Available from: http://www.census.gov/prod/2002pubs/p2 3-206.pdf. Accessed 1 July 2004. (Current Population Reports, Series P23-206).

24. United States, Census Bureau. United States Census 2000-summary file 3 . Available from: http:/ / www.census.gov. Accessed 1 July 2004.

25. SAS Institute Inc. SAS 8.2. Cary: SAS; 2003.

26. United States, Centers for Disease Control and Prevention. Epi Info version 6.04d. Atlanta: CDC; 2001.

27. StataCorp. Stata (7.0) statistical package. College Station: StataCorp; 2001.

28. Kenyon TA, Driver C, Haas E, Valway SE, Moser KS, Onorato IM. Immigration and tuberculosis among children on the United States-Mexico Border, County of San Diego, California. Pediatrics. 1999;104(1):e8.

29. Wells CD, Ocana M, Moser K, BergmireSweat D, Mohle-Boetani JC, Binkin NJ. A study of tuberculosis among foreign-born Hispanic persons in the U.S. states bordering Mexico. Am J Respir Crit Care Med. 1999;159: 834-7.

30. United States, Centers for Disease Control and Prevention. Essential components of a tuberculosis prevention and control program. MMWR. 1995;44(RR-11):1-16.

31. American Thoracic Society, Centers for Disease Control and Prevention, and Infectious Dis- 
eases Society of America. ATS/CDC/IDSA statement on the treatment of tuberculosis. Am J Respir Crit Care Med. 2003;167: 603-62.

32. World Health Organization. Guidelines for establishing DOTS-Plus pilot projects for the management of multidrug-resistant tuberculosis (MDR-TB). Geneva; WHO; 2000. (WHO/ CDS/TB/2000.279).
33. World Health Organization. Treatment of tuberculosis: guidelines for national programmes. Geneva: WHO; 1997. (WHO/TB/ 97.220).

34. United States, Centers for Disease Control and Prevention. Preventing and controlling tuberculosis along the US-Mexico border. MMWR. 2001;50(RR-1):1-27.
35. Institute of Medicine. Ending neglect: the elimination of tuberculosis in the United States. Washington, D.C.: National Academy Press; 2000.

Manuscript received 16 January 2004. Accepted for publication 18 June 2004.
RESUMEN

\section{La tuberculosis en la frontera mexicanoestadounidense}

Objetivos. La tuberculosis es un problema de salud pública importante y es una prioridad reconocida por los gobiernos federales de México y Estados Unidos de América. Los objetivos de la presente investigación fueron los siguientes, atendiendo específicamente a los cuatro estados de los Estados Unidos que tienen frontera con México: 1) describir la situación epidemiológica de la tuberculosis, 2) identificar los factores de riesgo de contraer la enfermedad y 3) examinar las estrategias aplicadas en los programas antituberculosos.

Métodos. Analizamos las notificaciones de casos de tuberculosis recogidas entre 1993 y 2001 por el sistema estadounidense para la vigilancia de la tuberculosis. Con esos datos se compararon los casos de tuberculosis detectados en tres grupos principalmente: 1) personas nacidas en México que vivían en uno de los cuatro estados fronterizos de Estados Unidos (Arizona, California, Nuevo México y Texas); 2) residentes de esos cuatro estados que habían nacido en los Estados Unidos, y 3) personas nacidas en México con residencia en cualquiera de los otros 46 estados de Estados Unidos que no tienen frontera con México.

Resultados. Durante el período de 1993 a 2001, 12450 (76,7\%) de los 16223 casos de tuberculosis en residentes de Estados Unidos nacidos en México se notificaron en Arizona, California, Nuevo México y Texas. En esos cuatro estados en general, la incidencia de tuberculosis en 2001 en personas nacidas en México fue 5,0 veces mayor que en personas nacidas en Estados Unidos. En dichos estados hay 23 condados que tienen frontera con México, y en ellos la razón observada fue de 5,8. Las probabilidades de que se notificaran seropositividad a VIH, abuso de alcohol, desempleo y encarcelamiento fueron menores, en grado significativo, entre pacientes tuberculosos nacidos en México con residencian en los cuatro estados fronterizos y en los otros estados que entre pacientes nacidos en Estados Unidos con residencia en los cuatro estados fronterizos $(P<0,001)$. Según el análisis multifactorial, en pacientes tuberculosos entre las edades de 18 y 64 años que vivían en los cuatro estados fronterizos las probabilidades de tener resistencia por lo menos a la isoniacida y la rifampicina (es decir, multirresistencia medicamentosa) eran 3,6 mayores cuando los pacientes habían nacido en México que cuando habían nacido en Estados Unidos. Asimismo, las probabilidades de tener resistencia a la isoniacida fueron dos veces mayores entre los pacientes nacidos en México que entre los nacidos en Estados Unidos. Los pacientes tuberculosos nacidos en México con residencia en los cuatro estados fronterizos y en los demás estados mostraron mayores probabilidades, en grado significativo, de haberse trasladado de lugar o de haber desaparecido durante el seguimiento que los pacientes tuberculosos nacidos en los Estados Unidos con residencia en los cuatro estados fronterizos $(P<0,001)$.

Conclusiones. Para poder eliminar la tuberculosis de los Estados Unidos, hace falta una mayor colaboración entre los gobiernos federales de este país y de México en lo que respecta a iniciativas para controlar la tuberculosis a lo largo de la frontera que comparten. 